\title{
Empowering Pamekasan to Become a Child- Friendly Regency through Interpersonal Communication
}

\author{
Umi Supraptiningsih \\ Sharia Faculty \\ State Islamic Institute of Madura \\ Pamekasan, Indonesia \\ umistainpamekasan@gmail.com \\ Ahmad Ghufran Ferdiant \\ Sharia Faculty \\ State Islamic Institute of Madura \\ Pamekasan, Indonesia \\ ghufran_ferdy@yahoo.com \\ Erie Hariyanto \\ Sharia Faculty \\ State Islamic Institute of Madura \\ Pamekasan, Indonesia \\ erie.mh@gmail.com
}

\author{
Eka Susylawati \\ Sharia Faculty \\ State Islamic Institute of Madura, \\ Pamekasan, Indonesia \\ ekasusylawati@gmail.com \\ Arif Wahyudi \\ Sharia Faculty \\ State Islamic Institute of Madura, \\ Pamekasan, Indonesia \\ ariyos.wahyudi@yahoo.com
}

\begin{abstract}
This paper discusses about the plan and implementation of one of Indonesian Government duties for giving facilities neither physically nor mentally for the sake of the manifestation of the protection and growth development of children. Pamekasan as one of regencies in Madura has developed a Child-Friendly Regency by developing a development system based on children rights through interpersonal communication in terms of the integration of commitment and resources of government, people, and business planned wholly and continually in policies, programs, and activities for fulfilling children rights for more than ten years since 2006. The objective of the present study is to examine how to empower Pamekasan to become a Child Friendly Regency through interpersonal communication. It used qualitative approach with participatory Action Research (PAR) as the research design. Whereas the result of the study showed that by the Decree of Pamekasan Regent No. 188/622/432.131/2013 on 13th Desember 2013 Pamekasan regency formed a duty force toward Child-Friendly Regency. Besides, there had been interpersonal communication among stakeholders by planning the region budget in terms of the needs of children education, growth development, and protection neither physically nor mentally and employing it to manifest Pamekasan as a ChildFriendly Regency. It is very beneficial for students and other researchers who are interested in learning further about children, policy, and interpersonal communication.
\end{abstract}

Keywords_pamekasan; child-friendly regency; interpersonal communication

\section{INTRODUCTION}

Chapter 27 verse (1) of the 1945 Constitution states that "All citizens of the State are at the same position in law and government and must uphold the law and government with no exception." It means that all Indonesian citizens without any distinction have equal rights to obtain legal protection. In chapter 1 verse (3) of the 1945 Constitution also affirms that the State of Indonesia is a State of law. Consequences of the article, the State must make law as a commander in the life of the nation and state.

The number of social problems which if we draw with the settlement of the law can result in the neglect of individual rights or individuals, while the individual rights must get protection from the State. Especially such individuals are those who are legally not yet have the ability to act alone in the fight for the rights. He can even be categorized as a "victim", for example underage children. Furthermore, the regulation on child protection is regulated further in various laws and regulations, such as in Law no. 23 Year 2002 Jo. UU No. 35 Year 2014 on Child Protection.

The state is very concerned about children to be able to realize their rights [1] because besides the children as the next generation, children are also very vulnerable to become victims. Even the cause of the loss of the rights of the child, one of them is the people who should be obliged to provide a protection for children but instead plunder their rights. The rising levels of violence against children are in terms of physical, psychic, and even sexsual violence [2]. The 
occurrence of such violence can occur anywhere either within homes, school environments, or even social environments where these children often hang out and play with each other. Externally, the negative impact of development, the rapid globalization in the field of technology, information and communications, and the economic can be the trigger of children committing a crime. Internally, the child's unstable personality condition becomes the root of the child's perverse behavior [3].

Personality of each individual is owned throughout his life. Through communication one can find himself, develop self-concept, and establish relationships with the world around, understand and comprehend about the opinions of individuals or a group. In discussing policies that come into contact with children, of course, we must communicate with children directly to know their needs and what they enjoy. In addition, it is important to communicate with child experts, community leaders, and some stakeholders who are perceived to be attached to the policy on Child- Friendly Regency. In this case, of course, a researcher will use interpersonal communication. Interpersonal communication is the delivery of a message by one person and the reception of a message by another person or a small group of people with its effects and opportunities to provide immediate feedback.

In 2002, Riggio conducted research entitled Child friendly cities: good governance in the best interests of the child. She described and explained about how the concept of child friendly cities developed, and its key role in ensuring the implementation of the Convention on the Rights of the Child in each city. The principles and practices of a child friendly city are illustrated by examples from Spain, the Occupied Territories of Palestine, Croatia, Ecuador, Brazil, India, Bangladesh, Sweden, Lebanon, Albania and the Ukraine [4]. While in 2012 Akbar and Ali conducted research entitled Planning Child-Friendly City (CFC) From Children's Perspective (Case Study: Quchan). Results of the study revealed more dimensions about what needs to be done with regards to implementing a successful CFC model in Quchan. The study also showed that domestic and international organizations like UNICEF and the Center for Intellectual Development of Children of Iran can play a key role in the establishment of a CFC project. Nevertheless, Iran currently lacks any specific action plan for the implementation of a CFC project in cities. In fact, most cities like Quchan are in elementary levels of moving toward CFC ideals [5]. Beside that, In 2014 Fatriani conducted research entitled Street Child and Child-Friendly City: A Study of Jambi City Government in Protecting Street Child to be Child-Friendly City. It is found that Jambi City Government has conducted effort in protection indicator field. It was conducted in order to lessen child street problem as well as effort to be child-friendly city. The policies implemented were setting up action committee for child labor elimination in Jambi City, monitoring and controlling in public place, performing coaching activity, job training and joint venture structuring group (KUBE), and providing school supply as well as relocating to certain social institution [6].

The previous studies above research and discuss about Child-friendly cities related to good governance in the best interests of the children, children's Perspective, and street child. Whereas the present study researches and discusses about an empowerment of potentials provided in Pamekasan Regency, East Java, Indonesia, Child- Friendly Regency, and interpersonal communication.

Therefore, it is going to examine how to empower Pamekasan to become a Child-Friendly Regency through interpersonal communication.

\section{RESEARCH METHODS}

This research used qualitative approach with Participatory Action Research (PAR) as the research design. The role of the researcher in this research was a full observer, whose status was known by the informants. While the location of research was conducted in Pamekasan. Sources of data in this study were obtained by establishing officials within the government of Pamekasan Regency as informants. The data collection technique used in this study were observation, interview and documentation.

Whereas the cycle of Participatory Action Research (PAR) in this research can be described as follows: (1) Social approach, (2) Identifying social data and facts, (3) Analyzing social data and facts to know potential of natural and human Resources of Pamekasan Regency, (4) Determining research question, (5) Organizing ideas on Child-Friendly Regency and interpersonal communication, (6) Planning programs, (7) Mobilizing human resources in Pamekasan in the form of socialization of predetermined program planning, (8) joint Action of Government, Stakeholder, and community of Pamekasan Regency, (9) Evaluating what has been done, and (10) Reflecting what has been done. In the process of implementing empowerment, we follow the steps of The PAR cycle above, although in sequence, it will but done flexibly.

\section{DISCUSSION}

It is said that Child-Friendly Regency is a regency which prepare whatever children need both physical and nonphysical needs. While the Child-Friendly Regency also means the regency that meets the indicators or defined the model of integrative development of regency in the context of the fulfillment of children's rights that means all development such as education, health, infrastructure, family and society are relevant to the needs of the children.

The birth of a Child-Friendly Regency policy is expected to create a family, neighbour, society or environment which cares children or child care, villages, districts or regencies that are friendly to children as a prerequisite to ensure that children grow and develop well, their rights are protected and their physical and psychological needs are fulfilled. To realize the Child-Friendly Regency, the regency governments need to make various efforts to integrate resources, issues of child 
protection and quality improvement into planning documents and implementation of government development, provincial and regency governments. Therefore, it is necessary to have a policy guidance of Child-Friendly Regency.

Child-Friendly Regency is a model of regency development that integrates the commitment and resources of government, society and the business world in order to fulfill the rights of children are planned holistically and sustainably [7, p. 17].

The scope of the child-friendly district policy covers development in the areas of health, education, protection, infrastructure, environment and tourism both directly and indirectly related to the implementation of child rights as stipulated in the Child Protection Act [7, p. 16].

Child-Friendly Regency policies covers financing, manpower, supervision and assessment, research and development aspects as well as representation of children's aspirations and interests in regency development decisionmaking.

Therefore, the government sees the need of policy of the Child-Friendly Regency as a first step in order to create a development that cares about children's rights, needs and interests. Because the principle of Child Friendly Regency policy is to encourage regencies to respect the rights of children that are manifested by:

- providing access to health services, education, clean water, healthy sanitation and free from environmental pollution ;

- providing policies and budgets for children ;

- providing a safe and comfortable environment, enabling the child to thrive. children can be creative, learn, interact socially, develop psychosocial and cultural expression ;

- balance in the social, economic, and protected fields from the effects of environmental damage and natural disasters ;

- paying special attention to children such as living and working in the street, sexual exploitation, living with disabilities or without parental support ;

- providing a platform for children to participate in decisions that directly affect their lives [7, pp. 13-14].

Similarly, in the Earth Summit in Rio de Janeiro, Brazil 1992, Heads of Government from all over the world agreed on the principles of Agenda 21, the Program of Action for Sustainable Development. Agreements in Chapter 25 of Agenda 21 are addressed to children and youth who specifically urge the government:

- implementing programs to reach the goals set by the world's world meeting for children ;

- emphasizing children's participation in environmental management;

- implementing the Convention on the Rights of the Child;

- expanding education for children, especially girls; and

- incorporating all child interests into all policies and strategies appropriate to sustainable development.

To create a Child-Friendly Regency, Pamekasan Regency Government needs to make various efforts to integrate child protection issues into the development planning document which of course it starts with communication effort, exactly interpersonal communication.
In order for the communication to run effectively, then the five qualities need to improve researchers, namely:

- Openness

The quality of openness refers to at least three aspects of interpersonal communication. First, an effective interpersonal communicator should be open to the person he or she interacts with especially about what the child needs and wants in Pamekasan Regency. Researchers also reacted openly to what other people say in relation with Child-friendly Regency.

- Empathy

Researchers are able to understand the motivations and experiences of others, their feelings and attitudes, their hopes and desires for the future. We can communicate empathy both verbally and non-verbally about the ChildFriendly Regency. Nonverbally, we can communicate empathy by showing (1) active engagement with that person through appropriate facial expressions and gestures; (2) centralized concentrations including the eye contact, the attentive posture, and the physical proximity; and (3) the proper touch or cares.

- Supportiveness

An effective interpersonal relationship is a relationship where there is a supportive attitude. Open and empathic communication can not take place in unfavorable conditions. We showed the attitude of support to the regency to be Child-Friendly Regency with some attitudes, namely: (1) descriptive, not evaluative, (2) spontaneous and not strategic, and (3) a provisional and not very confident.

- Positive attitude

Researchers communicate with people who talk about the Child-Friendly Regency with a positive attitude in her interpersonal communication with at least two ways: (1) expressing a positive attitude and (2) positively encouraging people to become our friends in interaction.

- Equality

In every situation, there may be inequality. One might be smarter. Richer, more handsome or beautiful, or more athletic than others. There are never two people who are truly equal in every way. Regardless of this inequality, interpersonal communication will be more effective when the atmosphere is equivalent. That is, there must be a tacit recognition that both parties are equally valuable, and each party has something important to contribute. In an interpersonal relationship characterized by equality, inconsistencies and conflicts are seen more as an attempt to understand the definite differences than as an opportunity to overthrow the other. Researchers highly appreciate the subjects interviewed about their opinions because they also want us to accept their opinions on Child-Friendly Regency in Pamekasan.

Physical and non physical facilities in order to manifest Pamekasan as a Child-Friendly Regency certainly accommodated the needs above, there needed to be adequate budgeting and really on target. The process of preparing the 
planning and budgeting documents was carried out in the following manner: From the first time the SKPD receives a letter of application for the Work Plan for next year in the form of a program, besides there was also a letter of request for the Activity Plan and budget submitted to the legal head of the Management Agency Office and this asset was a proposal or TOR. Furthermore, the two letters were verified. Usually verification from Bapeda was always approved but from the Management Board and asset office there was always a correction. After that there was a meeting of budget team of Activity and Budget Plan involving all ortaker. Then it was taken to the DPRD for discussion. The results of the deliberations were sent to the Province for evaluation, and the evaluation results were discussed in the DPRD, then the results of the deliberations are sent back to the Province. Lastly after the final was determined by the Regent in the form of a law, it was subsequently stated in the Budget Implementation List.

Budgeting from the Regional Budget and Expenditure Budget was proposed to the Budget Team consisting of budgeting: Physical, including submission of shelter (safe house) along with its facilities and infrastructure, Educational Game Equipment (proposed annually) by the target or its users for Bina Keluarga Todita and PAUD, supplementary school feeding targeted for elementary school children in 13 districts of Pamekasan Regency. Non-physical, including: Socialization to SKPD and Planning Team, Working Meeting with related working instances such as with task force, socialization and establishment of Children forum, Empowerment of Protection of Women and Children.

The target of Pamekasan as Child-Friendly Regency could be manifested within approximately five years. Some things must be prepared both physical and non physical needs. Preparation that should be done was the Local Regulation or Regulation of Regent that has been manifested with the Regional Regulation no. 14 of 2015 , the local Action Plan towards Child-Friendly Regency was the result of commitment of the Local Government Work Unit. In addition, there must be a similar vision with related institutions such as the Environment Agency, Public Works, Cipta Karya, while the Women's Empowerment and Family Planning Agency was in the front to coordinate and prepare the needs of children's rights in order to reach Child-Friendly Regency. Since 2010 Pamekasan was crowned as Child-Friendly Regency, one of the criteria met by Pamekasan regency that has been fulfilled, namely, the standard of population service and the fulfillment of birth certificate registration for children. However, until now the facilities that support Pamekasan to be ChildFriendly Regency was still inadequate. Therefore, the process of further empowerment was being done.

At UN Special Session on Children, May 2002, the mayors affirmed their commitment to actively voiced the rights of the child, and recommended to the mayors of the world to: (a) develop action plans to become Child-Friendly City; and (b) promote the participation of children as actors in the city's decision-making process, especially in the process of implementation and evaluation of city government policies [7, p. 21-22].
The meeting declared a Global Movement that helped build a world worthy of children with 10 commitments: (1) prioritizing children's interests, (2) eradicating poverty, (3) investing in children, (4) lesting a child be left behind, (5) caring for every child, (6) educating each child, (7) protecting children against abuse and exploitation, (6) protecting children from war, (8) combating HIV / AIDS, (9) listening to children and ensuring their participation, and (10) protecting the earth for children [7, p. 46].

In addition, the establishment of devices that prepare and support the implementation of Child-friendly Regency in the Regency. One of the devices was by forming the task force of Child-friendly Regency. A Task Force of Child-friendly Regency is a coordinating body composed of representatives from the executive, legislative and judiciary elements in charge of children, universities, non-governmental organizations, non-governmental organizations, the private sector, parents, and children. For regency or city that already has a Task Force / Team / Work Group associated with child protection, does not need to form a new task force but must adapt to the membership and job description of the task force of Pamekasan Regency based on Decision of Regent of Pamekasan Number 188/622 / 432.131 / 2013 dated December 13, 2013.

The main task of Task Force of Child-friendly Regency are: a) To coordinate the implementation of policies and the development of Child-friendly Regency; b) to define the duties of the Task Force members; c) to disseminate, advocate, facilitate and manifest the concept of Child-Friendly Regency; d) to collect basic data; e) to conduct a need analysis derived from the basic data; f) to disseminate the basic data; g) to determine the focus and priority of the program in realizing Child-friendly Regency , to adapt to local potential (key issues, needs, and resources); h) to develop Regency Action Plan of Child-friendly Regency (5 years) and working mechanism; i) to prepare Local Regulations on Regency Action Plans for Child-friendly Regency; and j) to monitor, evaluate and report at least once a year [7, p. 50].

The aims of the use of interpersonal communication in empowering Pamekasan to be a Child-friendly Regency, namely:

- Finding Yourself

Pamekasan managed to find his own identity according to the existing potential for the Child-Friendly Regency

- Discovering the Outer World

Researchers can understand Pamekasan further and deeper based on the information presented by individuals or groups in terms of designing Pamekasan into a ChildFriendly Regency through interpersonal communication.

- Shaping and Maintaining A Meaningful Relationship Researchers, Pamekasan Regency Government, community leaders, community and children could work together to empower Pamekasan to be Child-Friendly Regency and useful not only for Pamekasan Regency children but also for Pamekasan community in general.

- For Playing And Fun 
Children and Pamekasan community can relax, play and have fun with friends, relatives, or family in the city and district parks that have been provided by Pamekasan District Government.

- To help

The children and Pamekasan community are greatly helped by the availability of: access to health services, education, clean water, healthy sanitation and freedom from environmental pollution; policies and budgets for children, a safe and comfortable environment, good condition to develop. recreation, learning, social interaction developing psychosocial and cultural expression; balance in social, economic, and protection from the effects of environmental damage and natural disasters.

Supporting factors for the manifestation of Pamekasan as Child-Friendly Regency is the similarity of vision of all task force such as from Education Office, Public Works, Cipta Karya, Population and Civil Registry, Health Department, stakeholder outside government, Islamic and general organization, NGOs, academics, and the Women's and Family Planning Protection Agency as the front guard for the success of Passimony Child-Friendly Regency. Similarly, the commitment of the Regent and the Local Government Work Unit on the fulfillment of children's rights through funds or budgeting of physical and non physical activities, handling cases of children in a professional and sustainable way.

While the inhibiting factors are not yet understood by children's rights / regency Eligible Children by Local Government Work Unit, lack of commitment of Local Government Work Unit to manifest Pamekasan as ChildFriendly Regency, and not yet coordinated programs that go to Child-Friendly Regency in each Local Government Work Unit.

\section{CONCLUSION}

The empowerment of Pamekasan into a Child-Friendly Regency through interpersonal communication has been successfully manifested in physical and non-physical forms that are carried out towards the Child-FriendlyRegency Children and communities also benefit from the program's availability with the availability of: access to health services, education, clean water, healthy sanitation and freedom from environmental pollution ; policies and budgets for children , a safe and comfortable environment, good condition to develop. recreation, learning, social interaction developing psychosocial and cultural expression; balance in social, economic, and protection from the effects of environmental damage and natural disasters.

\section{SUGGESTION}

The office of Women's Empowerment and Family Planning Office Kab. Pamekasan as coordinator in implementing Pamekasan Regency as a Child-Friendly Regency should give understanding especially to the task force of the Child-Friendly Regency. It is expected that an integrated budgeting plan will be made by each SKPD in which it is aimed at fulfilling the rights of the children. With many cases of children in Pamekasan Regency, it will take time as soon as possible to manifest Pamekasan as a Child-Friendly Regency. It has become a necessity of understanding in the vision and mission in creating a ChildFriendly Regency; hence, it becomes a joint commitment to assist one another in supporting the implementation of the Child-Friendly Regency that is sustainable in Pamekasan.

\section{REFERENCES}

[1] N. A. Nugraheni, "Sistem Pemidanaan Edukatif Terhadap Anak Sebagai Pelaku Tindak Pidana [Educative Punishment System on Children as Offenders]," Masters Thesis, Law Studies, Diponegoro Univ., Semarang, Indonesia, 2009.

[2] U. Supraptiningsih, "Kesiapan Penegak Hukum Di Kabupaten Pamekasan Dalam Pemberlakuan UU No. 11 Tahun 2012 Tentang Sistem Peradilan Pidana Anak [Readiness of Pamekasan Regency's Law Enforcer on the Implementation of Law no. 11 year 2012 about Children Criminal Justice System],” Research Report, 2014.

[3] S. Sutatiek, "Politik Hukum UU No. 11 Tahun 2012 tentang Sistem Peradilan Pidana Anak [Law Politics of Law no. 11 about Children Criminal Justice System],” Var. Perad., no. 328, March 2013.

[4] Riggio, "Child friendly cities: good governance in the best interests of the child,” Int. Inst. for Env. and Develop., vol. 14, no. 2, pp. 1-30, 2002.

[5] R. Fatriani, "Street Child and Child-Friendly City: A Study of Jambi City Government in Protecting Street Child to be Child-Friendly City," Jurn. Manaj. Pemerint., vol. 1, no. 1, pp. 30-36, 2014.

[6] A. Akbar, "Planning Child-Friendly City (CFC) from Children's Perspective (Case Study: Quchan),” Bagh-I-Nazar J., vol. 9, no. 2, pp. 51-62, 2012.

[7] Deputy for Children's Protection, Pedoman Pelaksanaan Kebijakan Kabupaten/Kota Layak Anak [Guidance for Policy Implementation of Child-friendly Regency/City]. Jakarta: Ministry of Women Empowerment and Child's Protection, 2008. 